\title{
Family GPS Tracking for Android
}

Mafaz. M. Al-Anezi

mafazmhalanezi@gmail.com
Hisham D. Zebari

hisham89hisham89@gmail.com
Saad N. Birfkani

Sahil.mzeery@gmail.com

Department of Computer Science

College of Computer Science and Mathematics

University of Mosul, Mosul, Iraq

Received on: 19/03/2019

Accepted on: 29/08/2019

\section{ABSTRACT}

In smart phone field, the security, tracking lost and kidnapping prevention are one of the main areas in current days. Today family members safety is more important when they are outside home. So, there is a need for a tracking system for kids where the parents can monitor their kids at anytime from anywhere.

These security goals are achieved by the Android System, Global System for Mobile (GSM), Global Positioning System (GPS) and Short Message Service (SMS) technologies.

The proposed application must be installed in all family member's smart phones, and these smart phones will use GPS services without need for internet connection, where the GPS is used to locate the child specifically and to track the child whenever he changes his place. The location obtained by only depending on GSM by sending SMS which contain a link of Google map shows the information of the position. The application also has the ability to trigger a help SMS to his parents when the child is in a dangerous situation by using his headphone, and this is considering a help message in real time.

Keywords: Child Tracking System, GPS, SMS, Google map.

$$
\begin{aligned}
& \text { نظام تتبع وتحديد المواقع للعائلة في بيئة أندرويد }
\end{aligned}
$$

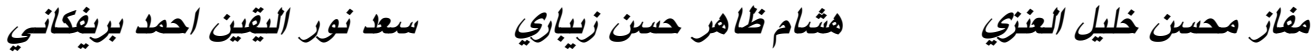

$$
\begin{aligned}
& \text { قسم علوم الحاسوب } \\
& \text { كلية علوم الحاسوب والرياضيات } \\
& \text { جامعة الموصل، الدوصل، العرلق }
\end{aligned}
$$

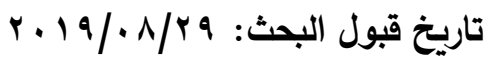

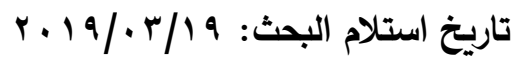

$$
\begin{aligned}
& \text { تتبع للأطفال حيث يمكن للوالدين مراقبة أطفالهم في أي وقت من أي مكان. } \\
& \text { ولتتحقق هذه الاهداف الامنية هنا يكون من خلال استخدام تقنيات نظام الاندرويد والنظام العالمي للجوال } \\
& \text { ونظام تحديد المواقع العالمي (GSM) وخدمة (GPS) وخدة الرسائل القصيرة (SMS). }
\end{aligned}
$$




$$
\begin{aligned}
& \text { فعند تثبيت التطبيق المقترح في جميع الهواتف الذكية الخاصة بأحد أفراد العائلة ، سوف تستخدم هذه }
\end{aligned}
$$

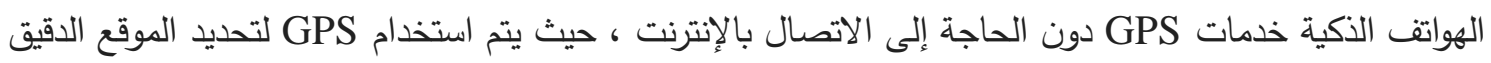

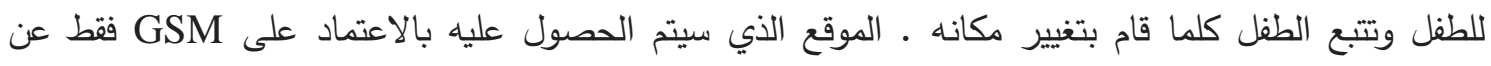

$$
\begin{aligned}
& \text { طريق إرسال رسائل قصيرة تحتوي على رابط من خريطة جوجل تظهر معلومات عن الموقع. التطبيق لديه أيضا }
\end{aligned}
$$

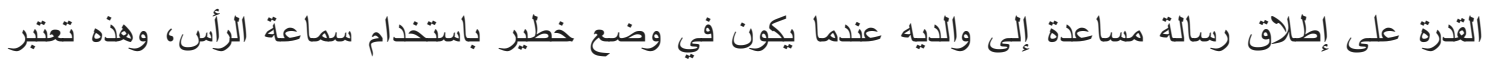

$$
\begin{aligned}
& \text { رسالة مساعدة في الوقت الحقيقي. } \\
& \text { الكلمات المفتاحية: نظام تتبع الطفل، نظام تحديد المواقع، الرسائل القصيرة، خريطة جوجل. }
\end{aligned}
$$

\section{Introduction}

In today's world, over $80 \%$ of people in the world having smart phones [8], the year 2018 is the first year where the use of smart phones will exceed the use of phones without operating system. According to the International Center for Missing and Exploited Children, about 8 million children are reported missing each year. This horrific number includes kidnappings in wars and even kidnappings by relatives and $90 \%$ of these children are found. But this does not eliminate the fact that these children who are absent from their families may be subject to persecution, harassment and human trafficking cases, some of whom lose their effect permanently. In addition to kidnapping there is also disappearance, where children ages 14 years and 17 years are missed or ran away from home [1]. In addition, if parents are planning to have a trip, they are always worried about their kids well fare. This concern may have an impact on the parents to have their children outside the house for any reason like going to school, playing with friends or even family trip. Moreover, parents can have their children out of sight and thus they are afraid of the possibility of having their children kidnapped.

Consequently, the proposed application is supposed to be used by parents with the purpose of helping to locate absent or unavailable kids. It is a well recognized fact that today's children have their own smart phones accompanying them almost all of the time. This can be of a great advantage in such a worrisome situation of a missing child. In this work, Global Positioning System (GPS) is utilized in conjunction with one of the fundamental services of a mobile which is SMS, the GPS uses longitude and latitude to track the location. This project has two sides, the application at the parents' side will permit parents to try to locate the child and then receive a reply about the position of the child on the Google map. On the child's smart phone side, information is collected to locate the smart phone. An application will be executed at the backend. The interplay between the parents and child's smart phones are executed through Short Message Service (SMS). A great and unique advantage of this SMS dependent application is that it can still be functioning in the absence of internet connection and even in the absence of General Packet Radio Service (GPRS) supporting software on the target smart phones. The system operates by locating the child's smart phone when the later sends a help SMS. Along with location the child may use Headphone to send a notification or help message to his parents that he is in danger.

\section{Previous Works}

Many studies have been done by researchers for this kind of applications, and they are different in the manner, tools and techniques. In Katore T.D. and others [4], their application "allows the parents to get their child's location on Google Maps and also their browsing history. The main responsibility of parent device is to send a request 
location SMS to child's device to get location of child. While the responsibility of child's device is to reply the GPS position to the parent's device upon request". Sucitra M. [8], his application "allows the parent to get their child's location on their mobile as notification. The system consists of two sides, child side and parent side. The child's device main duty is to sense the signals of an alert from the child and send a notification to the parent device. On the other hand, the parent's device main responsibility is to receive the notification from the child's device". Vanjire S. and others [10] "propose a developing Android Application which is based on Location Based Services (LBS) \& provides different location-based services like nearest friend locator, family member location finder". Shyam N. and others [7], "proposed system takes the advantage of the location services provided by GSM and GPS module kit, Radio Frequency Identification (RFID). Information such as GPS coordinates and time are gathered and sent to the parent's phone that's preregistered on the module kit. The communication between the parent and the child module kit is done using SMS".

\section{Contributions}

This paper describes location discovering and tracking system which aims at checking the child's welfare through his smart phone through achieving the following three objectives:

- This application represents an alarm system to the family that operates by sending an alert SMS to the parents when their children or family members send help SMS start with code "Location".

- The application also has the advantage of automatically sending an SMS to parents if the child takes off his head phone.

- The location data (Google Map) can be shared online.

\section{Application Requirements and Architecture}

\subsection{Global Positioning System (GPS)}

"The GPS is a space based on satellite navigation system that provides location and time information in all weather conditions, anywhere on or near the Earth where there is an unobstructed line of sight to four or more GPS satellites"[10]. The domains for the GPRS system are present in the united states and it is continually supplying data for a spectrum of purposes that range from the very sensitive military and national security issues to the simple driving and tourist guidance. The only one prerequisite for using this facility which is having a GPS access. [10]

GPS can be utilized by ordinary users as a navigation system. In practice, the GPS receiver containing devices uses the triangulation technique for positioning objects on the ground and for this purpose they derive data from at least the nearest three satellites. The outcome comes in the form of a spotted geographic location longitude and latitude. The programmers of software applications are racing to produce user friendly applications utilizing these available parameters to provide useful data for walking or driving instructions with high accuracy rate approaching figures as small as 10 meters. Being spotted by the GPRS can take some time especially when the target is in an overcrowded or moving situation as for example when driving a car in a crowded large city center. Initiation delay of the GPRS also depends on the starting method of its receiver. The starting time required for a GPS lock on a target is usually relied on how the GPS receiver starts. The preexisting data available for the receiver favors which satellite to look for according to the receiver's last position and accessibility of the satellites in the sky. This takes more time than a hot start but not as long as a cold start. 
Thus, it is more or less an opportunistic process to lock onto the signal of the nearest available satellite and is much the same like "polling" which is a time-consuming method when compared to have a fixed target satellite, see figure (1) [6].

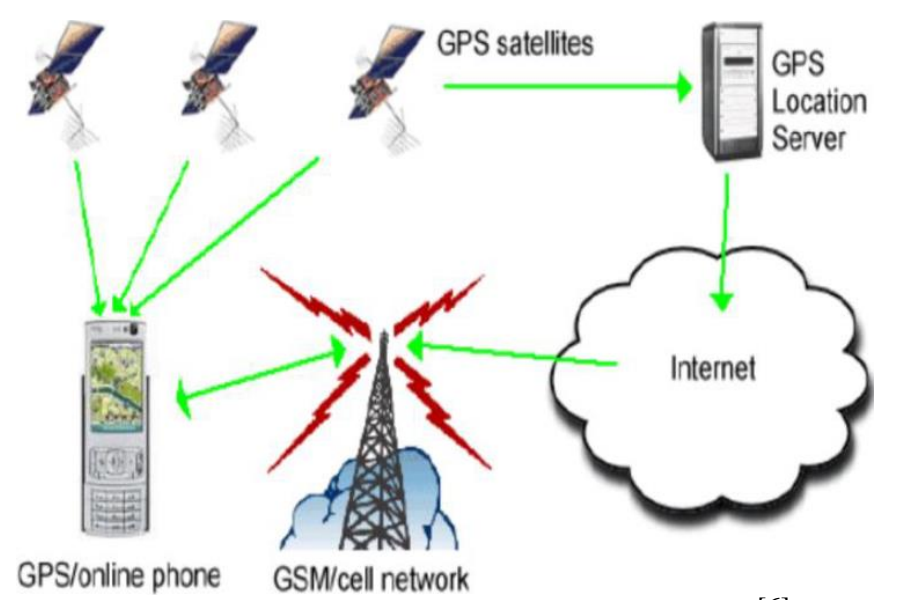

Figure 1: Architecture of GPS System. ${ }^{[6]}$

The innovative "assisted GPS Technology" was later introduced to overcome some of the delay problem on the expense of some memory consumption in the smart phone. This works by installing ephemeris when wireless connection is available, and this installed data can then use the cell phone towers to triangulate the user's location in a relatively short period. [10][5][3]

The structure GPS system is represented by three segments: the space segment, the control segment, and the user segment. The space segment is composed of a nominal constellation of 24 operating satellites that transfer one-way signals that give the current real time GPS satellite position. The control Segment traces the GPS satellites, uploads updated navigational data, and keeps health and status of the satellite constellation. The user segment is represented by the user's GPS receiver devise which analyses data from the space and control segments to specify the target's threedimensional real-time position. [1][5]

\subsection{Android: Mobile Operating System}

Android is a mobile operating system which uses one common approach to application development. Android software designers have to develop their own applications using this open source system. users can then install these applications and use them on any android operated device, namely smart phones. [3]

The main justification for choosing Android Operating System while designing this work was its huge popularity. It was announced that its market share has currently reached 48.8 and the rocketing number of android smart phone users is 91.4 in USA alone. [4]

Another advantage of android system is its Application Programming Interface (API) access to the Google maps through which the required locations can be plotted on the map by the user. [10]

\subsection{Google Maps}

Google Maps supply a map of an open API (Google Maps API). Developers can easily incorporate the Google Maps service into their application. [3]

The GPS supplies the smart phone devices with longitude and latitude coordinate which are then plotted on the map as symbols. Various extra properties were added for 
better utilization of these software's such as magnification and exploration of the surrounding areas by simply running the fingers over the mobile monitor. [5]

Through the known geographic location, this application helps the parents to follow a child's mobile device. Taking benefits of this technology by using available tools and free services like Google maps and GPS, we can establish a very reliable location tracking system. The basis of this program is GPS.

To develop this application Android Studio will be used. Android Studio is an enhancement tool that enables programmers to develop programs for several mobile phones. As a reference map Google Maps are used.

\subsection{Short Message Service (Sms)}

The contact between the parents and the child applications is done through SMS. SMS provides the system exceptional characteristics. It will permit the system to function in the absence of the availability of internet connection therefore permits the application to be worked on mobiles that don't support GPRS, 2G or 3G internet connectivity. The system sends the position of child's mobile to the parent's one when the parent likes to make sure on the child. [2][1]

The GPS uses longitude and latitude to track the location of SMS which is used to communicate both with child side and parent side applications. [6]

The system is able to send the child's mobile exact location to the parents' mobile when parent demand to check the child's location or the child sends notification for help by SMS start with code "Location".

\subsection{Application Development:}

This application is designed for both parents and children. The parents and children both should have mobiles that support GPS and SMS utilities.

The system to be developed is based on a simple basis, that is, the use of SMS for interact between the family members, parents and child. It is configured in an easy manner so that it will contain few components and less user interaction, thus it is made more user-friendly.

The design of Family GPS application to be carried out is depicted in figure (2), which comprises of two sides.

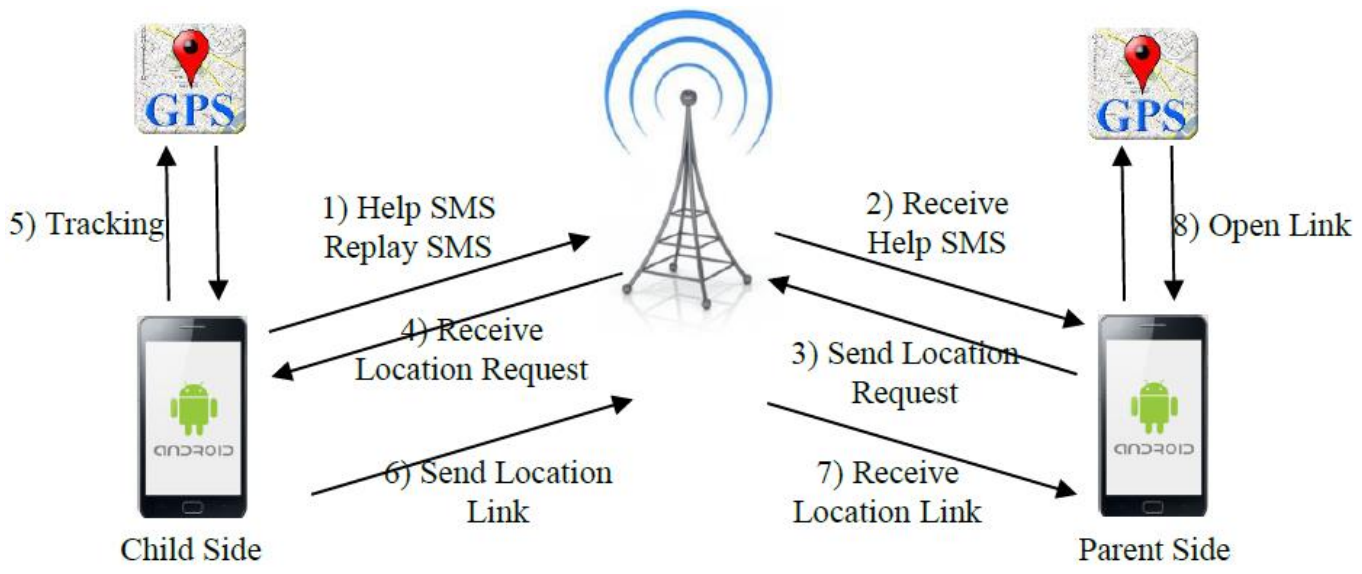

Figure 2: The Family GPS application architecture.

\section{- Parent side:}

This side conducts as a server for the system despite not being a real server. This alleged parent server can then utilize the SMS and available Google maps to spot the child's location. The prerequisites for this operation are availability of telephony and 
internet services.

In the parent side application, it begins with examining the existence of the child's mobile number saved in the contacts. If the number is not available, the application notifies the user for insertion and the application will store the number in the mobile. Next, if child sent a "Location" message, the application in the parent side requests the child's position by sending an SMS to the mobile of the child. The child's mobile would answer with the current position coordinates of the child. Finally, the application will handle the coordinates and display it in the Google map of the parent's mobile.

So, the parent can share the Google map with any other like police (which is the third objective), and the parent can also use GPS to determine his distance from his child. Figure (3) shows the Interface of the parents' side application and showing location of child by Google map.

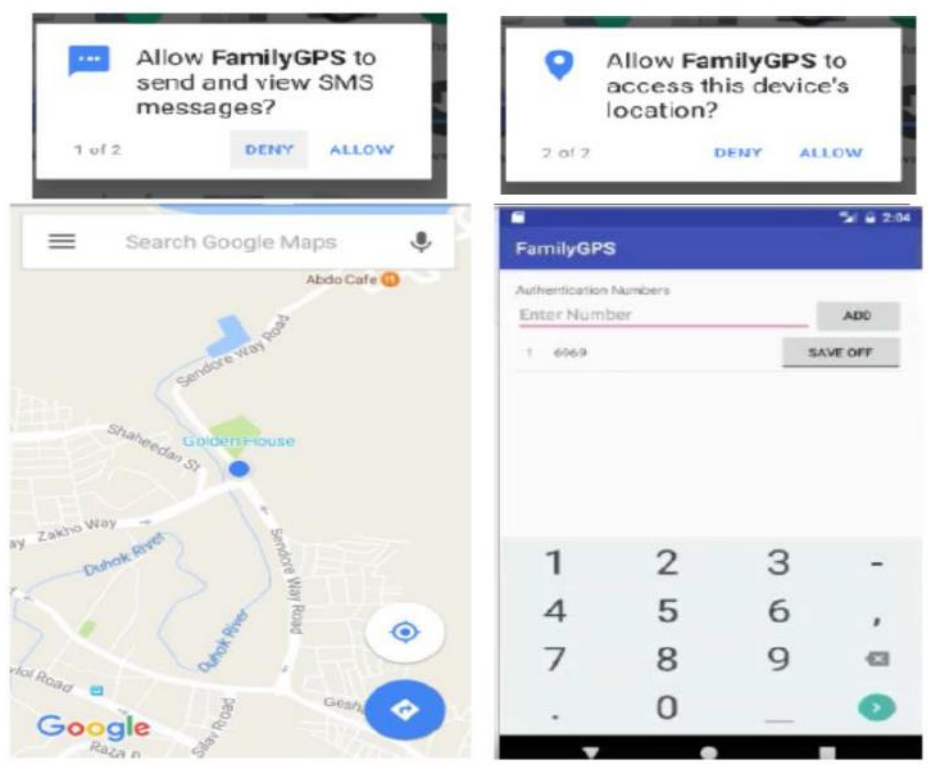

Figure 3: Interface of Family GPS application in parent side and google map showing child's location.

\section{- Child side:}

The child side is considered here as a client side for the system. The child side is similarly an Android mobile but is carried by the child at the time of location request. Hereby, location coordinates are derived from available GPS or network and are sent back to the parent through SMS. The difference here from the parent side is that child should also be in the range of the telephone towers regardless of the availability of internet services.

On the child side, mobile and location services must be activated and are operating on the child side for the system to begin working. After the location services check, another function is run to examine if the parent's mobile number have been entered. If the number has not been entered then notify the user to enter the numbers of the parents and save them in the favorite memory. Notice that this task must only be done by parents so it is secured by a password that must be only known to the parents.

Also, as we mention earlier as a second objective, in case that the child can't write SMS, he has the ability to notify his parent by takeoff head phone from his phone, and the application will automatically send the Location SMS.

\section{Conclusion And Future Work}

In conclusion, the proposed Family GPS application uses GPS, Android mobile 
and SMS in order to locating missing or lost children. The children effectively alert their parents about their position by sending SMS start with code "Location" or the SMS will be sent automatically by taking off the head phone from mobile. This location and position of children information can be obtained online from Google map. The application is cost efficient and does not need any additional device, it only needs smart phones.

As a future work, the suggested system can be applied to notify parents via SMS when the children enter or leave the school, enabling the school administration and parents to keep track of the bus online, or specifying different safety zones if the child get out of them, the application will notify the parents via SMS.

\section{Acknowledgement}

The authors would like to acknowledge and thank University of Mosul, College of Computer Sciences \& Mathematics for supporting the research work. 


\section{REFERENCES}

[1] Abdullah M., Bashier H., Sayeed S., Yusof I., Al Mazloum A. and Omer E.," GPS and SMS-based Child Tracking System using Smart Phone", Australian Journal of Basic and Applied Sciences, 7(13) November 2013, Page No. 133-138.

[2] Al-Mazloum A., Omer E. and Abdullah M.,"GPS and SMS-Based Child Tracking System Using Smart Phone", International Journal of Electrical, Computer, Energetic, Electronic and Communication Engineering Vol:7, No:2, 2013, Page No. 238- 241.

[3] Kadibagil M. and Guruprasad H.,"Position Detection and Tracking System", International Journal of Computer Science and Information Technology \& Security (IJCSITS), Vol. 4, No. 3,June 2014, Page No. 67- 73.

[4] Katore T., Ghogare G., Shinde D., Ghule T. and .Tamhane K., "Android Parental Tracking", International Journal Of Engineering And Computer Science, Volume 4 Issue 3 March 2015, Page No. 10764-10767.

[5] Kinage R., Kumari J., Zalke P. and Kulkarni M., "Mobile Tracking Application", International Journal of Innovative Research in Science, Engineering and Technology Vol. 2, Issue 3, March 2013, Page No. 617- 623.

[6] Satish M., Nandlal C. and Sandip G. ,"Child Tracking System using Android phones", International Journal of Advanced Research in Computer Engineering \& Technology (IJARCET) Volume 4 Issue 4, April 2015, Page No.1257- 1260.

[7] Shyam N., Kumar N., Shashi M. and Kumar. D. "SMS Based Kids Tracking and Safety System by Using RFID and GSM", International Journal of Innovative Science, Engineering \& Technology (IJISET), Vol. 2 Issue 5, May 2015, Page No. 793-799.

[8] Sucitra.M, "Child tracking system using smart phones without expenditure of money", International Journal of Advanced Computer Technology (IJACT), VOLUME 5, NUMBER 2, APRIL 2017, Page No. 84-86.

[9] Tekawade A., Tutake A., Shinde R., Dhole P. and Hirve S., "Mobile Tracking Application for Locating Friends using LBS", International Journal of Innovative Research in Computer and Communication Engineering Vol. 1, Issue 2, April 2013, Page No. 303- 308.

[10] Vanjire S., Kanchan U. , Shitole G. and Patil P., "Location Based Services on Smart Phone through the Android Application", International Journal of Advanced Research in Computer and Communication Engineering Vol. 3, Issue 1, January 2014, Page No. 4982- 4987. 